\title{
FAMILY FIRMS: COVID-19 CHALLENGES AND FUTURE OUTLOOK
}

\author{
Dr. Anandi Banerjee \\ Assistant Professor of Finance \\ Queens University of Charlotte, USA \\ E-mail: anandibanerjee85@gmail.com
}

Received: July 02, 2021

Accepted: October 30, 2021

Online Published: December 05, 2021

DOI: 10.46281/ijafr.v9i1.1477

URL: https://doi.org/10.46281/ijafr.v9i1.1477

\begin{abstract}
The COVID-19 pandemic endangered the survival of many firms and emphasized the need to reevaluate corporate strategy. This paper studies the impact of the pandemic on family businesses and how it changed their strategy, priorities, and outlook. We use data from the PricewaterhouseCoopers $(P w C)$ Family Business Survey 2021 that covers 2,801 family firms in 87 countries. Our study highlights some of the challenges family businesses faced during the pandemic and the need for an updated blueprint to ensure their long-lasting success. The survey draws attention to the financial resilience of family businesses and their unique advantages in terms of reputation and trust. However, it also underscores the need for family firms to adopt a more focused environment, social and governance (ESG) agenda, and to invest in technological transformation. The paper analyzes the congruity between academic research and CEO responses and forms a bridge between the academic literature on family firms and the real-world surveys of CEOs of family businesses conducted by $P w C$.
\end{abstract}

Keywords: Family Firms, Resilience, ESG Agenda, Technological Transformation, COVID-19.

JEL Classification Codes: G32, M10, M53, L20, L21.

\section{INTRODUCTION}

"You have family-owned businesses that have been around for 500 years. You cannot name a corporation that survives intact for even a few decades."

-Nassim Nicholas Taleb

Family businesses account for more than half of the global GDP and employ about two-thirds of the global workforce (PwC Family Business Survey, 2021). However, the unique strengths of family businesses - their superior resilience and agility-are often overshadowed by the charm and attractiveness of unicorns and younger corporations. Nevertheless, the strong fundamentals of these family firms are an asset during an unexpected global economic shock. In 2009, family businesses rebounded faster from the financial crisis than did non-family firms. Zhou et al. (2017) studied the performance of non-financial firms in the S\&P500 between 2006 and 2010 and found that family firms 
outperformed their non-family counterparts. This outperformance is attributable to the lower predisposition of family firms to boost short-term earnings during times of crisis by overinvesting in risky projects.

Family firms are perceived as more trustworthy businesses, as is confirmed by the Edelman Trust Barometer, which showed that $67 \%$ of the respondents trusted family businesses to do what is right. This was in response to the survey question: "Thinking about different types of businesses, please indicate how much you trust each type of business to do what is right?" In contrast, only $60 \%$ and $58 \%$ of the respondents said that they trusted privately owned and public enterprises, respectively. The Edelman survey identifies competence and ethics as the main factors in building trust. These unique traits in family businesses allow them to score higher than other organizations when one includes competence and ethics simultaneously.

A survey of the top 750 global family businesses highlights the contributions of these businesses to the resilience of the world economy (Bain, 2020). These 750 companies had an aggregate revenue of USD 10.3 trillion in 2019, up from USD 9.1 trillion in 2018. They employed 33.6 million people in 2019, compared to 30.5 million in 2018. The survey indicated that these businesses started 2020 with sound balance sheets, suggesting that they were better positioned to weather the COVID-19 pandemic than many of their non-family counterparts.

The COVID-19 pandemic ushered in a crisis that was very different from previous economic downturns. Corporations faced disruptions in their supply chains, struggled to continue operations due to lockdown measures, and faced a severe lack of demand. Our paper uses survey data collected by PricewaterhouseCoopers $(\mathrm{PwC})$ to highlight unique perspectives on family businesses during the economic downturn triggered by the pandemic. This survey was conducted before the rollout of any vaccine. Figure 1 shows that family businesses expected the effect of the COVID-19 pandemic on future growth would be more deleterious than the financial recession of 2008. It contrasts the responses to the 2021 PwC Survey Question: "Looking back over the last financial year, before the COVID-19 pandemic, would you say your sales have been...?" with the historical responses to a similar question: "Looking back over the last financial year, would you say your sales have been..."

2007-20 I 8 Survey Q: Looking back over the last financial year would you say your sales have been...

2021 Survey Q: Looking back over the last financial year, before the COVID-19 pandemic, would you say your sales have been... And what do you think the impact of the COVID-19 pandemic will be on your sales?

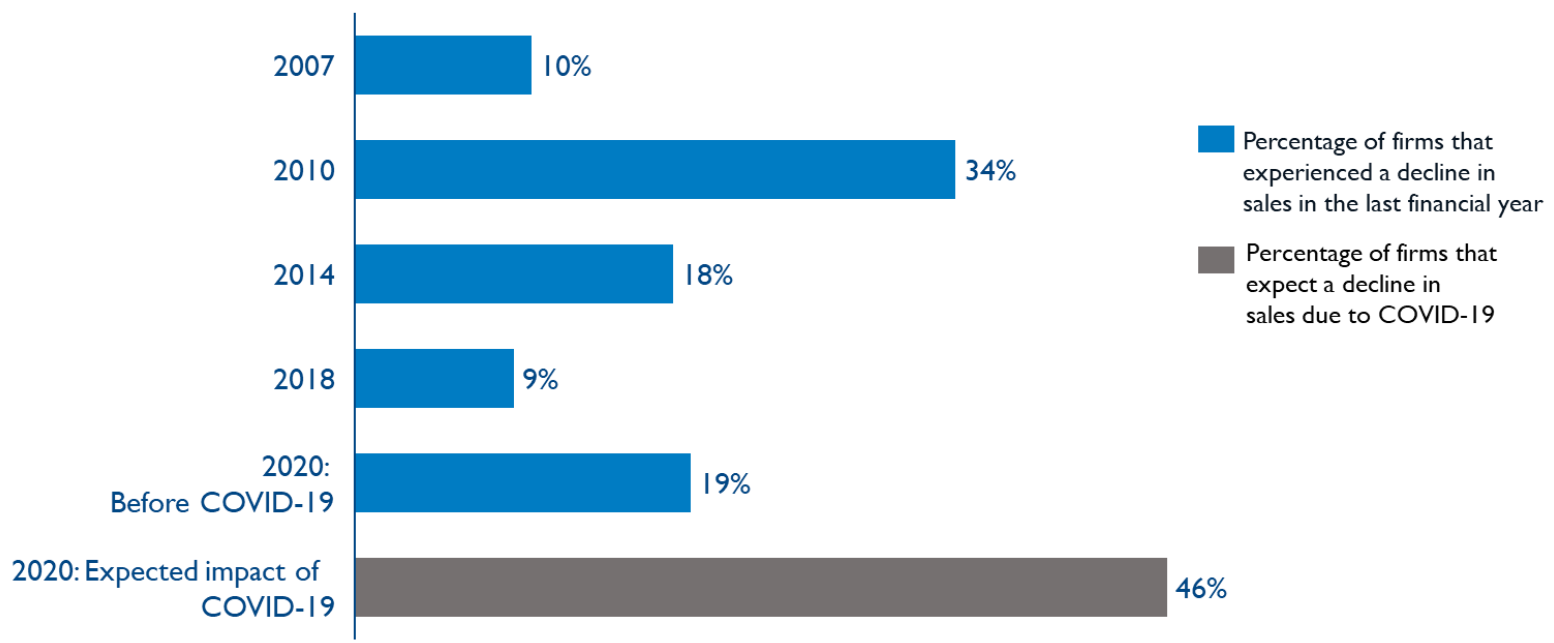

Figure 1. Family businesses expect the COVID-19 pandemic to impact growth more than the great recession did

Source: PwC Family Business Survey 2021 
The surveys report that in $2010,34 \%$ of the family firms had experienced a decline in sales in the past financial year. This is much lower than the $46 \%$ of the family businesses that expected to see a decline in sales due to the COVID-19 pandemic.

This paper studies the current academic research on the impact of the COVID-19 pandemic on family businesses and the characteristics of family businesses that made them more resilient during the pandemic. We use survey data collected in 2020 to discuss how CEOs and decision-makers of family businesses perceived their performance and what changes are required in these businesses. Finally, we analyze the congruity between academic research and CEO responses. Our paper forms a bridge between the academic literature on family firms and the real-world surveys conducted by PricewaterhouseCoopers.

The rest of the paper is organized as follows. Section 2 describes the data. Section 3 presents the survey results, discusses the academic literature related to the survey findings, and throws light on how the survey results align with existing literature. Section 4 concludes.

\section{DATA}

We use the data from the Family Business Survey, 2021, conducted by PwC in collaboration with Family Business Network International (FBN) due to the credibility of the organization and the breadth of the family firms surveyed. The survey covered owners and executives of family businesses with a wideranging yearly turnover spanning USD 5 million to USD 6 billion. The data was collected from October 5, 2020, to December 11, 2020.

In the tenth edition of the survey, the organization collected data on 2,801 family businesses in 87 territories and then conducted panel discussions with family business leaders to test their findings. The panel discussions used a semi-structured script and were conducted in the native language of the country where the research took place. The duration of these interviews ranged from 20 to 35 minutes. The pool of respondents was restricted to the primary decision-makers in the family firms. The following section describes the results of the survey and interprets these results.

\section{RESULTS AND DISCUSSION}

The survey highlights the primary characteristics of family firms, which have been known to focus on building a legacy and emphasizing the long-term success of the business. We discuss four critical attributes of family firms: financial resilience; environment, social and governance (ESG) agenda; technological transformation; and changes in family dynamics. Based on the PwC Survey, we also discuss areas of improvement revealed in the survey.

\section{Financial Resilience}

Family owners consider their firms as legacies to be passed on to the next generation (Casson, 1999). Steier (2005) argues that due to the long-term outlook of family firms and the owners' focus on legacy preservation and intention of succession within the family, maintaining financial resilience is particularly important. These non-economic goals mitigate agency problems and increase the efficiency of family firms. McConaughy et al. (2001) suggest that family-controlled firms generally have a longer-term outlook and are less willing to take risks as compared to non-family firms. Duran et al. (2016) show that although family firms invest less in innovation than their non-family counterparts, they have an increased conversion rate of innovative input into an output that eventually leads to higher innovation output.

Amann and Jaussaud (2012) highlight family firms' superior ability to withstand economic downturns as compared to their non-family counterparts. Family firms have more flexibility, as is evident 
from the higher cash to current asset ratios. Japanese family firms were able to mobilize resources more efficiently in the period following the Asian crisis and recover faster than non-family firms.

Stock returns of family firms during the pandemic have been superior to those of their non-family counterparts. Ding et al. (2021) study the relationship between the characteristics of a corporation and the sensitivity of its stock's return to COVID-19 cases. Their paper takes an international perspective, conducting a study on 6700 firms across 61 economies. The authors find that the firm's financial stability before the pandemic, particularly with respect to higher cash levels, access to credit, lower short-term debt, lower leverage, and higher profits, guaranteed better stock performance. Firms that are highly dependent on international supply chains and customers were more vulnerable to a significant variation in market valuation due to the pandemic. Higher international exposure created the fear of supply chain disruptions and lowered the favorable perception of these firms.

Q: Which of the following best describes your company's ambitions for 2021 and 2022 ?

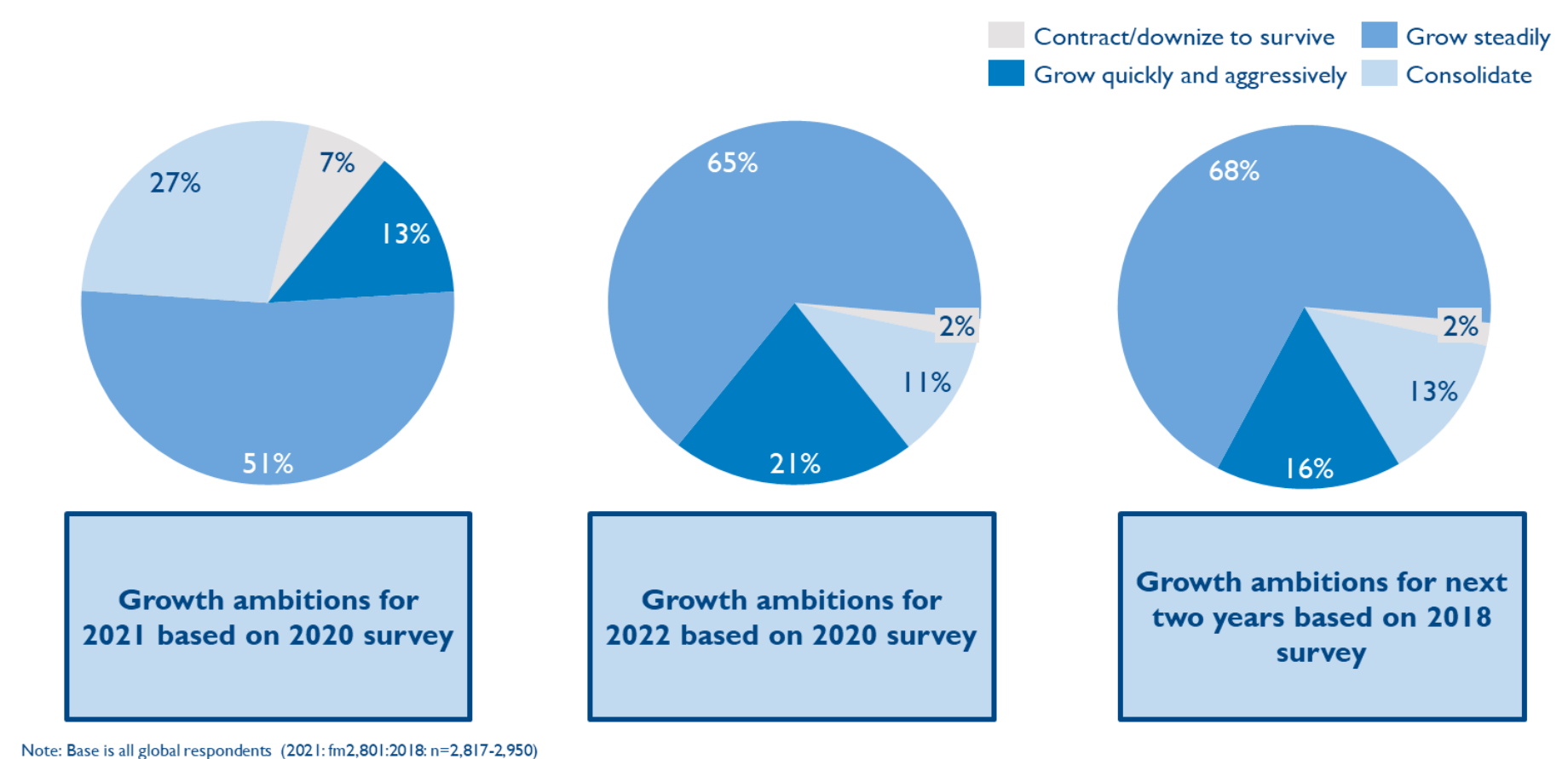

Figure 2. Growth expectations over the next two years

Source: PwC Family Business Survey 2021

Our paper explores the financial resilience of family firms in a global context during the pandemic-induced economic downturn. The survey shows that $79 \%$ of the firms did not require additional capital in 2020, and only $34 \%$ had to decrease dividends during this period. Moreover, only $31 \%$ of family members had to take a salary reduction due to decreased profitability during the pandemic. Although $21 \%$ of the family firms had to raise capital, the confidence of the family members in the business was evident from the feedback that $15 \%$ of the owners invested their own cash during the pandemic, and a further $23 \%$ said that they were ready to do so if necessary. Figure 2 presents the response to the following survey question: "Which of the following best describes your company's ambitions for 2021 and 2022?"

Survey responses showed optimism about growth, and most family businesses foresee future profitability. Particularly, 64\% of the firms expect to grow in 2021, while $86 \%$ expect to see growth in 2022. Comparing the results from the 2020 survey with those from the 2018 survey, as in Figure 2, we 
find the following: growth ambitions in 2021 are lower than expected, but those for 2022 correspond to the ambitions reflected in the 2018 survey, where $84 \%$ of the firms expected to grow in the next two years. Thus we conclude that the 2020 survey highlights the resilience of family firms in the economic downturn, allowing them to bounce back to a growth outlook similar to that in 2018 .

\section{ESG Agenda}

Due to the massive interest shown by consumers and investors, ESG factors have long been a strategic concern for corporations worldwide. Based on a survey conducted in 2017, the five urgent global challenges included economic inequality, technological disruption, demographic pressures, the polarization of opinion and declining trust (PwC, 2020). These issues have been driven further into the forefront and have deepened due to the pandemic. Based on a report by the OECD, the pandemic caused a shift in public sentiment and has highlighted economic and societal vulnerabilities.

Since family firms are considered more trustworthy by their stakeholders and are not as sensitive to short-term market pressures as their non-family counterparts, they have a natural edge in sustainability. Moreover, privately held family businesses have a head start when it comes to a long-term perspective on investment in sustainable initiatives. Nevertheless, survey responses indicate that although family firms are keen on implementing ESG practices, their pace has not kept up with their goals.

Respondents to the survey were asked the following question: "Which, if any, of the following are the company's top five priorities for the next two years?" The results, depicted in Figure 3 , show that expansion and diversification is a top-five priority for $82 \%$ of the family firms, followed by digital and technological innovation (80\%). On the other hand, sustainability is a priority for only $39 \%$ of the companies. A detailed analysis highlights that $55 \%$ of the firms feel that they can make steady headway in incorporating sustainability into their businesses. However, only $37 \%$ of the firms have already crafted a sustainability strategy. Thus, there is a gap between translating the family's core values into concrete actions that reflect ESG commitment.

The responses also show that although family firms have the opportunity to lead on ESG practices, they do not face the same pressure from their stakeholders regarding ESG implementation as do publiclylisted non-family firms. Nevertheless, growth may hinge on faster and more thorough ESG adoption.Due to the massive inflows in ESG funds in recent years and the regulations enforcing sustainability practices such as gender pay reporting and disclosures of emissions, it has been imperative for listed companies to include ESG practices.

As evident from Figure 3, "expanding into new markets/client segments" is the top priority for family businesses. Since stakeholders and regulators favor firms committed to sustainability, regulations in different markets and geographies could motivate family businesses to prioritize investments in this area. Prioritizing ESG will be vital for family firms to ensure their licenses to operate in existing markets, expand into new markets, and preserve their legacy.

Another roadblock faced by family firms is their interpretation of ESG. The PwC survey reports that giving back is in the DNA of family businesses. Traditionally, these firms are concerned about their reputation and give greater importance to employee welfare and support for their communities. Most family businesses (over $80 \%$ ) believe in social responsibility, and more than $40 \%$ are engaged in philanthropy. However, there is significant variation regarding the interpretation of sustainability among family firms across the globe. In China, $79 \%$ of family businesses prioritize sustainability compared to $23 \%$ of the family businesses in the US. However, commitment to the community is more substantial among family firms in the US (76\%) than those in China (54\%).

Although family businesses give tremendous importance to reputation building, family firms have different agency problems than non-family firms regarding their ESG investments (Abeysekera and 
Fernando, 2020). El Ghoul et al. (2016) show that the lower ESG performance of family firms is driven by conflicting interests between the family owners and the minority shareholders. This difference is more evident among family-controlled firms in emerging economies. Family firms often believe in "giving back" to society in a traditional sense via contributions to charity. In fact, instead of a strategic approach to ESG investments, about $75 \%$ of US-based family firms and $60 \%$ of British family firms preferred to make direct charitable or social contributions. Canavati (2018) demonstrates a negative relationship between public family firms and corporate social performance, which is more pronounced in countries with weaker labor and corporate governance regulations.

However, society's expectations for businesses are rising. Particularly, younger consumers believe that companies have a responsibility to address environmental and social issues. They think that environmentally and socially focused companies are better prospective employers, and the vast majority say they would be more loyal to companies aligned with those values. Moreover, Albuquerque et al. (2019) show that systematic risk is significantly lower for firms with higher corporate social responsibility (CSR) factors. A firm's adherence to these factors has been used as a product differentiation strategy to attract consumers. Lins et al. (2017) showed that firms with high CSR scores exhibited superior performance during the financial crisis of 2008-2009. Ding et al. (2021) find that higher levels of pre-pandemic CSR activities have provided immunity to more pronounced stock price fluctuations. Finally, Rolandi (2020) shows that companies with superior ESG scores outperformed their peers during the first wave of COVID-19 infections. Thus it is imperative for family firms to plan for growth based on sustainability and prioritized ESG principles.

\section{Q: Which, if any, of the following are the company's top five priorities for the next two years?}

\section{Company priorities by topic (not percentages)}

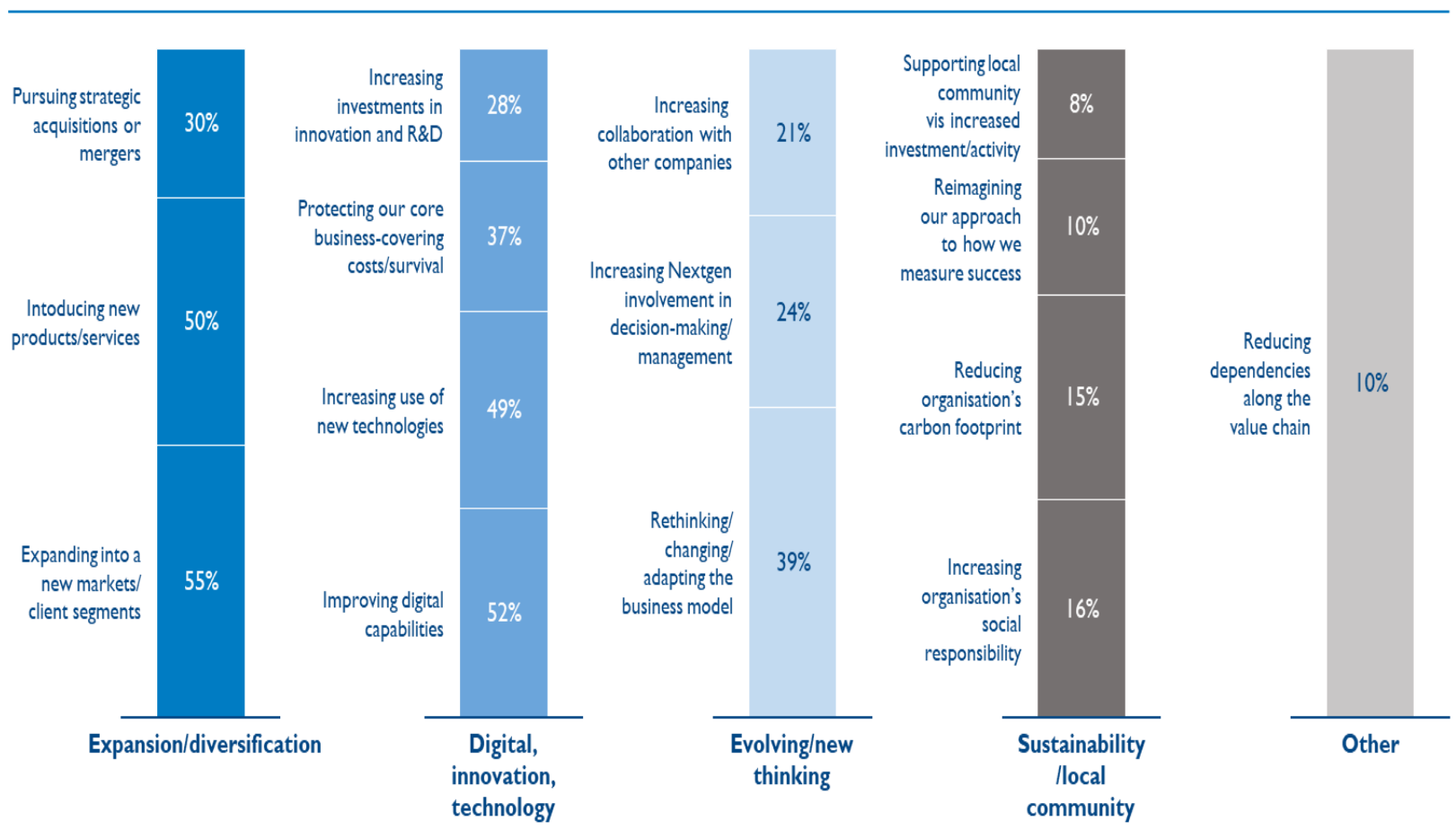

Figure 3. Top priorities for the next two years Source: PwC Family Business Survey 2021 


\section{Technological Transformation}

Although family businesses are less inclined to invest heavily in innovation than their non-family counterparts due to their higher levels of risk aversion (Chrisman \& Patel, 2012; Block, 2012; GomezMejia et al., 2007; De Massis et al., 2018; Erdogan et al., 2020; Rondi et al., 2021), they are able to generate higher innovation efficiency ( Duran et al., 2016). This has been attributable to the higher autonomy and decision-making powers of the owner-manager (Craig and Moores, 2015), and efficient and quicker approval process for investments related to innovation (Hiebl, 2015).

Digitalization is an important component of innovation and technological transformation, using digital technologies to enhance value and generate income (Gartner, 2020). Digitalization raises productivity and reduces costs, thus increasing efficiency. Existing literature highlights the distinct path taken by family firms in their journey to digitalization. Hu and Hughes (2020) show that families avoid radical innovation plans and innovate in an incremental fashion. These firms emphasize on preserving their socioemotional wealth, and adopt innovative and risky initiatives mostly when their performance does not meet their expectations (Chrisman \& Patel, 2012; Munoz-Bullon et al., 2020). Nevertheless, despite their risk aversion, some of the most innovative firms in the world are family-owned (De Massis et al., 2016).

The pandemic created an unprecedented situation that called for radical technological transformation. Having a strong digital capability was of utmost importance during the pandemic. The survey results highlight the advantages of digitalization and report that firms with advanced technological capabilities outperformed other firms during the COVID-19 crisis. Strong digital capability also ensured a smoother transition to remote work for employees. The survey highlighted the following results:

- Investing in technological and digital advancement is a top priority for $80 \%$ of the surveyed family firms. However, only $19 \%$ of family businesses believe that their digitalization process is complete, whereas $62 \%$ say that they still need to do more in their technological transformation journey.

- Twenty-nine percent of the respondents state that they still lack the strong digital capabilities necessary to meet the challenges of today's world. Although the strengthening of digital capabilities is the second-highest priority in the survey, the development of these capabilities did not rank high in the action plan for these family firms.

Figure 4A shows the direct relationship between strong digital capabilities and superior performance. The responses highlight that technological transformation has aided businesses via multiple channels.

Based on the responses, we find that family businesses with strong digital capabilities expected and experienced better growth and performance than did their counterparts with less developed digital capabilities. During the pre-COVID period, $60 \%$ of the family firms with strong digital capabilities experienced positive growth. This is in comparison to $51 \%$ of their low-digital counterparts. Moreover, $32 \%$ of family businesses with strong digital capabilities anticipate positive growth after the COVID impact. On the other hand, only $26 \%$ of the firms that lack advanced digital capabilities expect positive growth. Looking ahead, $71 \%$ of firms with high digital capabilities anticipate an expansion in 2021, and $88 \%$ expect an expansion in 2022. This is higher in comparison to $61 \%$ of other family businesses that expect to see growth in 2021 and 85\% that expect growth in 2022. 


\begin{tabular}{|c|c|c|}
\hline & $\begin{array}{l}\text { Percentage of family business with } \\
\text { strong digital capabilities }\end{array}$ & $\begin{array}{l}\text { Percentage of other } \\
\text { family businesses }\end{array}$ \\
\hline \multicolumn{3}{|c|}{ Panel A: Firm Performance } \\
\hline Pre COVID growth & $60 \%$ & $51 \%$ \\
\hline Expect growth after COVID & $32 \%$ & $26 \%$ \\
\hline Expect to grow in 2021 & $71 \%$ & $61 \%$ \\
\hline Expect to grow in 2022 & $88 \%$ & $85 \%$ \\
\hline \multicolumn{3}{|c|}{ Panel B: Agility } \\
\hline More transparent information sharing & $73 \%$ & $58 \%$ \\
\hline Adjust quickly due to liquidity & $71 \%$ & $50 \%$ \\
\hline Access to reliable data & $86 \%$ & $54 \%$ \\
\hline \multicolumn{3}{|c|}{ Panel C: Sustainability } \\
\hline Focus on Sustainability & $60 \%$ & $42 \%$ \\
\hline Developed channels to communicate sustainability strategy & $51 \%$ & $29 \%$ \\
\hline
\end{tabular}

Figure 4. Importance of Digital Capability

Source: PwC Family Business Survey 2021

The pandemic threw light on the importance of agility, which refers to the ability to respond quickly to challenges or a crisis and figure out prompt, effective solutions. Improved agility was crucial during the COVID-19 crisis since companies needed to adapt rapidly to volatile markets, and demand and supply issues. The survey responses highlight the compelling differences between the agility of companies with strong digital capabilities and that of other family firms.

Digital capabilities helped family businesses share information among family members promptly and improve transparency. Seventy-three percent of family businesses with strong digital capabilities reported greater transparency in comparison to 58\% of their counterparts. This improvement in transparency and having access to timely information and reliable data helped the managers of these family firms make efficient and quick decisions, thus increasing the agility of these firms. The advantages of digitalization are most perceptible in the survey responses based on agility. Figure 4B demonstrates that $86 \%$ of the technologically advanced family businesses could make use of timely and valid information to make decisions. On the other hand, only $54 \%$ of the family firms without strong digital capabilities could access prompt and reliable information and data for decision-making. Liquidity was a crucial factor during the pandemic, and efficient liquidity management led to greater agility. $71 \%$ of the well-digitalized family businesses were able to swiftly change course by managing their liquidity. However, only $50 \%$ of other family businesses were able to make quick changes based on liquidity.

The survey also shows that digital capabilities allow firms to better focus on sustainability. Figure $4 \mathrm{C}$ demonstrates that $60 \%$ of the well-digitalized family businesses use sustainability as a core principle, compared to $42 \%$ of the other family firms. Well-developed digital capabilities equip these firms to communicate their decisions around sustainability to all stakeholders. Fifty-one percent of these firms have a strategy to communicate decisions related to sustainability, as compared to only $29 \%$ of other family firms. These responses highlight the importance of digital transformation and how family firms with strong digital capabilities outperformed other family firms. 


\section{Changes in Family Dynamics}

De Massis \& Rondi (2020) contend that the pandemic and its aftermath will prompt salient changes in family businesses. They argue that succession planning may become more critical with the pandemic emphasizing the awareness of mortality among the leadership cohort.

Figure 5A displays the response to the question "How important to you are the following longerterm goals, i.e., over the next five years or longer?" in the 2018 and 2021 surveys. A comparison of the long-term personal goals for family firms in 2021 compared to those in 2018 shows that the pandemic has strengthened their priorities in protecting the business (a top priority for 82 percent of respondents in 2021 vs. 76 percent in 2018), creating a legacy (64 percent vs. 61 percent) and ensuring that the business stays in the family (65 percent vs. 61 percent). Although family ties are instrumental in the success of family firms, these firms have realized the need to take a more professionalized approach to governance with formal succession planning.

\begin{tabular}{|c|c|c|}
\hline \multicolumn{3}{|c|}{ The top long-term priorities for family businesses } \\
\hline Top long-term priorities & Percentage of firms in 2021 & Percentage of family firms in 2018 \\
\hline $\begin{array}{l}\text { Protect the business as the most } \\
\text { important family asset }\end{array}$ & $82 \%$ & $76 \%$ \\
\hline $\begin{array}{l}\text { Ensure the business stays in the } \\
\text { family }\end{array}$ & $65 \%$ & $61 \%$ \\
\hline Create a legacy & $64 \%$ & $60 \%$ \\
\hline $\begin{array}{l}\text { Create dividends for family } \\
\text { members }\end{array}$ & $63 \%$ & $57 \%$ \\
\hline $\begin{array}{l}\text { Create employment for other } \\
\text { family members }\end{array}$ & $23 \%$ & $20 \%$ \\
\hline
\end{tabular}

Figure 5A. A Comparison of the Long-term priorities of family firms in 2021 and in 2018 Source: PwC Family Business Survey 2021

The survey also highlights the need for family firms to ensure more transparent communication and effective resolution of disagreements. Comparing the survey results from 2021 with those from 2018 reveals that the pandemic has accentuated the need to address sensitive issues related to family dynamics. Figure 5B shows that fewer respondents in 2021 feel that the family has a clear sense of agreed values and purpose for the business (68\%) than did respondents in 2018 (79\%). The pandemic highlighted the lack of emergency and contingency procedures for family firms, with only $19 \%$ of the respondents saying that their businesses had these procedures in place. This is about half of the percentage of respondents in the 2018 survey, i.e., $36 \%$, who believed that their firms had emergency and contingency procedures in place. This disparity was also evident in the respondents' views regarding conflict resolution mechanisms. Only 15\% of respondents in 2021 believed that their companies had effective conflict resolution mechanisms compared to $30 \%$ in the 2018 survey. 
The survey highlights the changes in family sentiment due to the pandemic. The crisis served as an opportunity for executives of the family firms to take a deep dive into issues around having a clear sense of agreed values and purpose as a company, a well-documented mission and vision, and a welldefined code of conduct. The pandemic shed light on the shortcomings of the family firms and provided the opportunity to reevaluate, improve and formalize the family firms' missions.

\begin{tabular}{|c|c|c|}
\hline $\begin{array}{l}\text { Values and purpose } \\
\text { sentiment }\end{array}$ & Percentage of family business in 2021 & Percentage of family business in 2018 \\
\hline $\begin{array}{l}\text { Clear sense of agreed values and } \\
\text { purpose as a company }\end{array}$ & $68 \%$ & $79 \%$ \\
\hline $\begin{array}{l}\text { Documented vision and purpose } \\
\text { statement(mission) for the } \\
\text { company }\end{array}$ & $51 \%$ & $68 \%$ \\
\hline $\begin{array}{l}\text { The family have a defined code of } \\
\text { conduct }\end{array}$ & $47 \%$ & $66 \%$ \\
\hline $\begin{array}{l}\text { Family have family values and } \\
\text { mission for the company } \\
\text { articulated in written form }\end{array}$ & $44 \%$ & $49 \%$ \\
\hline
\end{tabular}

Figure 5B. A Comparison of the Values and Purpose Sentiment in 2021 and in 2018 Source: PwC Family Business Survey 2021

\section{CONCLUSION}

The COVID-19 crisis has underscored the need for a richer governance model that focuses on the financial health and resilience of the company. The public-private partnership model incorporated in dealing with various facets of the crisis has shown that society's wellbeing hinges on effectively governed companies. Not only are companies an avenue to maximize shareholder return and continue the financial cycle, but they are also a means to provide for the basic needs of the society.

The pandemic caused an upheaval in the pre-existing business structures and norms, and has served as a wake-up call for firms all around the world. The social and economic effects of the pandemic are challenging the advancement of family firms, which now need to innovate to thrive in the altered economy. Our paper uses the PwC Family Business Survey 2021 to study how the COVID-19 pandemic changed family firms' strategy, priorities, and outlook. The main takeaways from the survey highlight the financial resilience of family firms and their adaptability to changes across generations. It shows that family-controlled firms pursue a purpose-driven business model and focus on long-term performance and responsible ownership. However, the survey and our analysis also shed light on family firms' blind spots and their need for a strategic approach and commitment to sustainability and technological transformation.

\section{REFERENCES}

Abeysekera, A. P., \& Fernando, C. S. (2020). Corporate social responsibility versus corporate shareholder responsibility: A family firm perspective. Journal of Corporate Finance, 61, 101370. 
Albuquerque, R., Koskinen, Y., \& Zhang, C. (2019). Corporate social responsibility and firm risk: Theory and empirical evidence. Management Science, 65(10), 4451-4469.

Amann, B., \& Jaussaud, J. (2012). Family and non-family business resilience in an economic downturn. Asia Pacific Business Review, 18(2), 203-223.

Block, J. H. (2012). R\&D investments in family and founder firms: An agency perspective. Journal of Business Venturing, 27(2), 248-265.

Canavati, S. (2018). Corporate social performance in family firms: a meta-analysis. Journal of Family Business Management, 8(3), 235-273.

Casson, M. (1999). The economics of the family firm. Scandinavian Economic History Review, 47, 1023.

Chrisman, J. J., \& Patel, P. C. (2012). Variations in R\&D investments of family and non-family firms: Behavioral agency and myopic loss aversion perspectives. Academy of management Journal, 55(4), 976-997.

Craig, J. B., \& Moores, K. (2015). The A-GES framework: Understanding the family business difference. In S. L. Newbert (Ed.), Small business in a global economy: Creating and managing successful organizations (pp. 123-154). Santa Barbara: Praeger.

Bain, D. (2020) The World's Top 750 Family Businesses Ranking. Family Capital. Retrieved from https://www.famcap.com/the-worlds-750-biggest-family-businesses.

De Massis, A., Frattini, F., Majocchi, A., \& Piscitello, L. (2018). Family firms in the global economy: Toward a deeper understanding of internationalization determinants, processes, and outcomes. Global Strategy Journal, 8(1), 3-21.

De Massis, A., Frattini, F., Kotlar, J., Petruzzelli, A. M., \& Wright, M. (2016). Innovation through tradition: Lessons from innovative family businesses and directions for future research. Academy of Management Perspectives, 30(1), 93-116.

De Massis, A., \& Rondi, E. (2020). COVID-19 and the future of family business research. Journal of Management Studies, 57(8), 1727-1731.

Ding, W., Levine, R., Lin, C., \& Xie, W. (2021). Corporate immunity to the COVID-19 pandemic. Journal of Financial Economics, 141(2), 802-830.

Duran, P., Kammerlander, N., Van Essen, M., \& Zellweger, T. (2016). Doing more with less: Innovation input and output in family firms. Academy of Management Journal, 59(4), 1224-1264.

Edelman Trust Barometer (2021). Retrieved from https://www.edelman.com/trust/2021-trust-barometer. 
El Ghoul, S., Guedhami, O., Wang, H., \& Kwok, C. C. (2016). Family control and corporate social responsibility. Journal of Banking \& Finance, 73, 131-146.

Erdogan, I., Rondi, E., \& De Massis, A. (2020). Managing the tradition and innovation paradox in family firms: A family imprinting perspective. Entrepreneurship Theory and Practice, 44(1), 20-54.

Gómez-Mejía, L. R., Haynes, K. T., Núñez-Nickel, M., Jacobson, K. J., \& Moyano-Fuentes, J. (2007). Socioemotional wealth and business risks in family-controlled firms: Evidence from Spanish olive oil mills. Administrative Science Quarterly, 52(1), 106-137.

Hiebl, M. R. (2015). Agency and stewardship attitudes of chief financial officers in private companies. Qualitative Research in Financial Markets, 7(1), 4-23.

Hu, Q., \& Hughes, M. (2020). Radical innovation in family firms: a systematic analysis and research agenda. International Journal of Entrepreneurial Behaviour and Research, 26(6), 1199-1234.

Lins, K. V., Servaes, H., \& Tamayo, A. (2017). Social capital, trust, and firm performance: The value of corporate social responsibility during the financial crisis. The Journal of Finance, 72(4), 17851824.

McConaughy, D. L., Matthews, C. H., \& Fialko, A. S. (2001). Founding family controlled firms: Performance, risk, and value. Journal of Small Business Management, 39(1), 31-49.

Muñoz-Bullón, F., Sanchez-Bueno, M. J., \& De Massis, A. (2020). Combining internal and external R\&D: The effects on innovation performance in family and non-family firms. Entrepreneurship Theory and Practice, 44(5), 996-1031.

PwC, Global Family Business Survey (2018). The values effect, 2018. Retrieved from https://www.pwc.com/gx/en/services/family-business/family-business-survey-2018.html.

PwC, Five urgent global issues and implications (2020). Retrieved from https://www.pwc.com/gx/en/issues/assets/pdf/pwc-adapt-five-urgent-global-issues-andimplications-may.pdf

PwC, Global Family Business Survey (2021). From trust to impact, 2021. Retrieved from https://www.pwc.com/gx/en/services/family-business/family-business-survey-2018.html.

Rolandi, A. (2019). Investors Increasingly Turning To ESG, Report Finds. Funds europe.com. Retrieved from https://www.funds-europe.com/news/investorsincreasingly-turning-to-esg-report-finds.

Rondi, E., Überbacher, R., von Schlenk-Barnsdorf, L., De Massis, A., \& Hülsbeck, M. (2021). One for all, all for one: A mutual gains perspective on HRM and innovation management practices in family firms. Journal of Family Business Strategy, 100394.

Steier, L. (2005). Executive succession in entrepreneurial business. The Blackwell Encyclopedic Dictionary of Entrepreneurship, 2, 125-128. 
Zhou, H., He, F., \& Wang, Y. (2017). Did family firms perform better during the financial crisis? New insights from the S\&P 500 firms. Global Finance Journal, 33, 88-103.

\section{Copyrights}

Copyright for this article is retained by the author(s), with first publication rights granted to the journal. This is an open-access article distributed under the terms and conditions of the Creative Commons Attribution license (https://creativecommons.org/licenses/by/4.0). 